\title{
Tetrazole derivatives and matrices as novel cobalamin coordinating compounds
}

\author{
Sergey N. Fedosov ${ }^{\mathrm{a}, *}$, Lars Berglund ${ }^{\mathrm{b}}$, Ebba Nexø ${ }^{\mathrm{c}}$, Torben E. Petersen ${ }^{\mathrm{a}}$ \\ ${ }^{a}$ Protein Chemistry Laboratory, Department of Molecular Biology, University of Aarhus, Science Park, Gustav Wieds Vej 10, 8000 Aarhus C, Denmark \\ ${ }^{\mathrm{b}}$ Cobento A/S, Science Park, Gustav Wieds Vej 10, 8000 Aarhus C, Denmark \\ ${ }^{\mathrm{c}}$ Department of Clinical Biochemistry, AS, Aarhus University Hospital, Norrebrogade 44, 8000 Aarhus C, Denmark
}

Received 27 June 2006; received in revised form 16 August 2006; accepted 16 August 2006

Available online 1 September 2006

\begin{abstract}
Cobalamin ( $\mathrm{Cbl}$, vitamin $\mathrm{B}_{12}$ ) consists of two moieties: (i) the corrin ring with the central Co-ion in the oxidation states $\mathrm{Co}^{3+/ 2+/ 1+}$ and (ii) the nucleotide side chain. The lower position of the ring is typically occupied by the nucleotide base (Bzm), whereas the upper surface coordinates exchangeable ligands. We have found that amino-tetrazole can coordinate to $\mathrm{H}_{2} \mathrm{O} \cdot \mathrm{Cbl}\left(\mathrm{Co}^{3+}\right)$ with $K_{\mathrm{d}}=10^{-5}$ $10^{-6} \mathrm{M}$. A specific group (presumably tetrazole, TZ) can be easily created in CNBr-activated Sepharose by treatment with $\mathrm{N}_{3}^{-}$. The prepared matrix (STZ) contained $\approx 10 \mathrm{mM}$ of the active groups, which bound $\mathrm{H}_{2} \mathrm{O} \cdot$ corrinoids with $K_{\mathrm{d}}=10^{-5}-10^{-6} \mathrm{M}$. Stability of STZ$\mathrm{Cbl}$ bonds gradually increased and reached $K_{\mathrm{d}}=10^{-7} \mathrm{M}$ over $10-20 \mathrm{~h}\left(20^{\circ} \mathrm{C}, \mathrm{pH}\right.$ 6-7). This effect can be ascribed to partial displacement of Bzm and coordination of TZ to the lower position. The binding was most efficient at $\mathrm{pH} 4-7$ and low ionic strength, yet, noticeable adsorption took place even at extreme conditions, $\mathrm{pH} 1-9$ and $I=0-2 \mathrm{M}$. Reduced corrins $\left(\mathrm{Co}^{2+}\right)$ also exhibited high affinity for STZ. The bound ligands could be eluted as $\mathrm{H}_{2} \mathrm{O} \cdot \mathrm{Cbl}(\mathrm{pH}), \mathrm{HO} \cdot \mathrm{Cbl}(\mathrm{pH} 14)$ or diCN $\cdot \mathrm{Cbl}\left(\mathrm{pH} 9-12, \mathrm{CN}^{-}\right)$. The adsorbent is applicable for one-step purification of corrins from a crude extract; separation of aquo- and diaquo-forms; specific capturing of $\mathrm{H}_{2} \mathrm{O} \cdot \mathrm{Cbl}$ from a mixture containing organo-Cbls or protein-bound $\mathrm{Cbl}$, analysis of peptide-Cbl dissociation kinetics, etc.
\end{abstract}

(c) 2006 Elsevier B.V. All rights reserved.

Keywords: Tetrazole; Amino-tetrazole; Azide; Cobalamin; Corrinoid; Coordination; Adsorbent; Sepharose

\section{Introduction}

Vitamin $\mathrm{B}_{12}$ (or cobalamin, $\mathrm{Cbl}$ ) is an organometallic cofactor of complex structure $[1,2]$. It is synthesised only by bacteria, and all other organisms obtain the vitamin via a complicated food chain $[3,4]$. Insufficiency of vitamin

\footnotetext{
Abbreviations: ATZ, amino-tetrazole; Bzm, 5',6'-dimethyl-benzimidazole base; Cbl, cobalamin; Ado $/ \mathrm{Me} \cdot / \mathrm{H}_{2} \mathrm{O} \cdot / \mathrm{CN} \cdot \mathrm{Cbl}$, cob(III)alamins with $\beta$-coordinated $5^{\prime}$-deoxy-5'-adenosyl, methyl, water, cyanide, respectively; Cbi, cobinamide; GSH, reduced glutathione; His, histidine; Im, imidazole; $\mathrm{P}_{i}$, sodium-phosphate buffer; RTZ, 1-substituted tetrazole; STZ, Sepharose with tetrazole groups; TZ, tetrazole.

* Corresponding author.

E-mail address: snf@mb.au.dk (S.N. Fedosov).
}

$\mathrm{B}_{12}$ in humans causes severe disorders accompanied by neurological abnormalities, anaemia and death, if not treated $[3,4]$.

The core architecture of $\mathrm{Cbl}$ (Fig. 1a) includes the corrin ring with a central cobalt ion and the nucleotide loop with a $5^{\prime}, 6^{\prime}$-dimethyl-benzimidazole base (Bzm) coordinated to cobalt at the lower axial position $\left(\alpha\right.$-site). Many $\mathrm{B}_{12}$-producing microorganisms also synthesise different $\mathrm{B}_{12}$-analogues, which have missing or/and substituted elements in the core structure $[1,2]$. The most typical natural analogues are (i) intermediate products of $\mathrm{Cbl}$ synthesis, e.g. a baseless precursor cobinamide (Cbi); and (ii) the complete corrinoids with a nucleotide base differing from Bzm.

Cobalamins with the correct backbone may contain different active groups coordinated to cobalt at the upper 


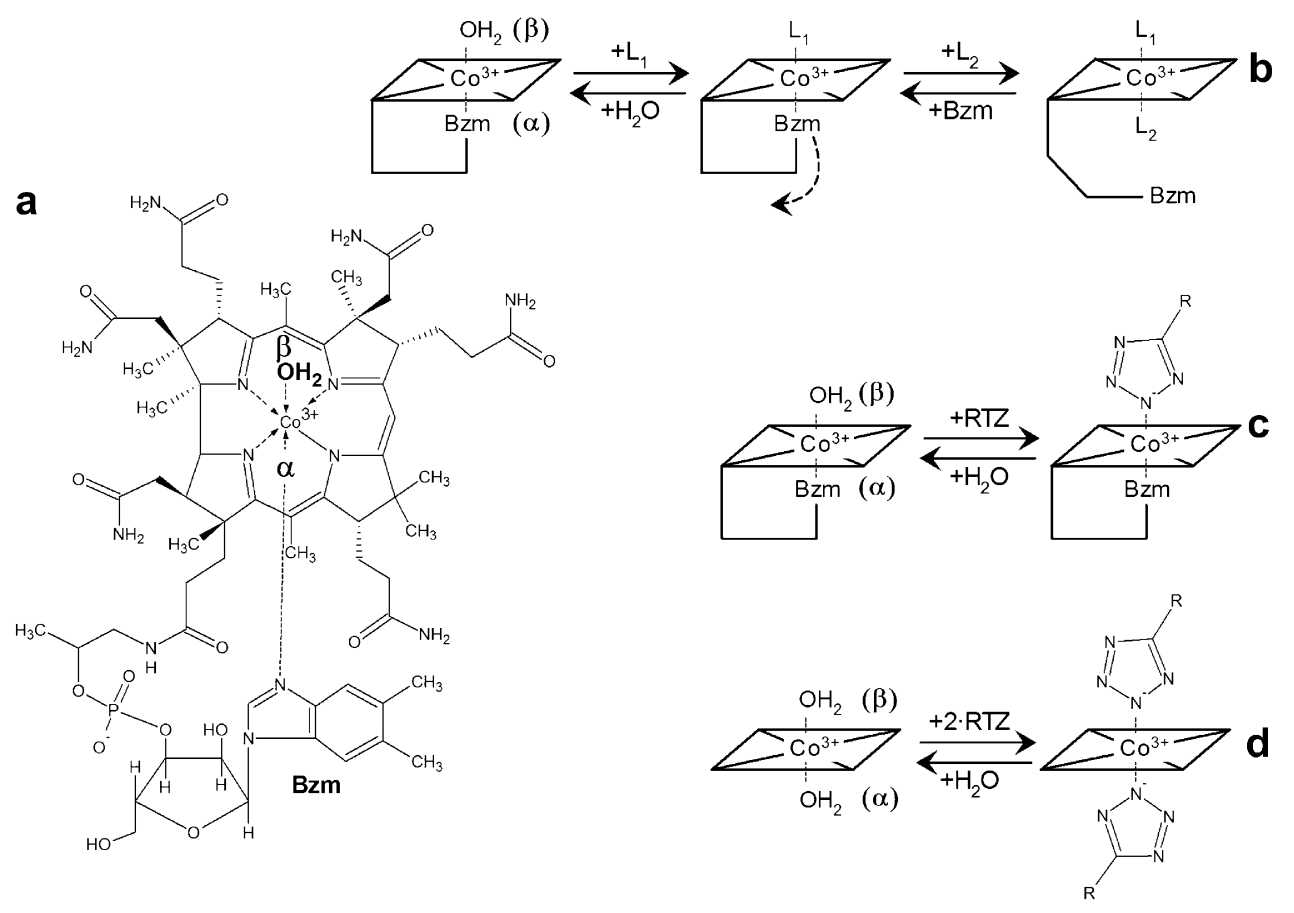

Fig. 1. Structure of $\mathrm{H}_{2} \mathrm{O} \cdot \mathrm{Cbl}$ and its axial coordinations. (a) Structure of $\mathrm{H}_{2} \mathrm{O} \cdot \mathrm{Cbl}$ where the Bzm-base and water are coordinated to the lower ( $\alpha$ ) and upper $(\beta)$ axial positions, respectively. (b) Displacement of the original axial ligands of $\mathrm{H}_{2} \mathrm{O} \cdot \mathrm{Cbl}$ by external ligands $\mathrm{L}_{1}$ and $\mathrm{L}_{2}$. (c) Coordination of a tetrazole derivative (RTZ) to the upper position of $\mathrm{H}_{2} \mathrm{O} \cdot \mathrm{Cbl}$. (d) Coordination of two tetrazole derivatives (RTZ) to diaquo-cobinamide.

axial position ( $\beta$-site): water, cyanide, histidine, etc. [1,2]. Yet, all variants of $\mathrm{Cbl}$ can be converted inside the animal cell to the cofactors methyl- and 5'-deoxy-5'-adenosylcobalamin $(\mathrm{Me} \cdot \mathrm{Cbl}$, Ado $\cdot \mathrm{Cbl})$, which catalyse reactions of methylation and isomerization, respectively [5]. The carbon-cobalt bond of the two above cofactors is sensitive to light and chemical environment, and it can be easily cleaved under specific conditions [1,2,5]. As a consequence, $\mathrm{Ado} \cdot \mathrm{Cbl}$ and $\mathrm{Me} \cdot \mathrm{Cbl}$ can be converted to $\mathrm{H}_{2} \mathrm{O} \cdot \mathrm{Cbl}$ in oxygenated aqueous solutions. This makes $\mathrm{H}_{2} \mathrm{O} \cdot \mathrm{Cbl}$ (vitamin $\mathrm{B}_{12 \mathrm{a}}$ ) the third ubiquitous form of natural cobalamins.

Water of $\mathrm{H}_{2} \mathrm{O} \cdot \mathrm{Cbl}$ is a weakly associated axial ligand which can be readily displaced from the $\beta$-site of $\mathrm{Cbl}$ by a number of other chemicals, for instance $\mathrm{CN}^{-}$ $\left(K_{\mathrm{d}}<10^{-12} \mathrm{M}\right)$, ionized sulfhydryl of cysteine or glutathione $\left(K_{\mathrm{d}}=10^{-6} \mathrm{M}\right)$, imidazole $\left(K_{\mathrm{d}}=10^{-4} \mathrm{M}\right)$, different amino-groups $\left(K_{\mathrm{d}}=10^{-3} \mathrm{M}\right)[1]$. The ligands with highest affinity can also displace the Bzm-base from its lower $\alpha$ position and form homologous or heterologous axial pairs, as is schematically shown in Fig. 1b. Various combinations of axial ligands have been obtained for baseless analogues, where $\alpha$-contacts are simplified by absence of Bzm [1,2]. Affinity of an axial ligand for the corrin ring depends on the nature of the opposite group and the degree of cobalt oxidation $[1,2]$. In an oxygenated solution $\left[\mathrm{H}_{2} \mathrm{O} \cdot \mathrm{Co}^{+3}\right] \mathrm{Cbl}$ is a by far prevailing form, which binds a variety of organic and inorganic substances. On the contrary, corrins with chemically or electrochemically reduced cobalt $\left(\mathrm{Co}^{2+}\right.$, $\mathrm{Co}^{1+}$ ) bind axial ligands weaker or do not bind them at all.
Coordinating properties of corrinoids are of potential use for adsorption of $\mathrm{H}_{2} \mathrm{O} \cdot \mathrm{Cbl}$ from a crude solution. This approach might be advantageous in comparison with an unspecific binding to charcoal or different resins, for example, Amberlite XAD. Yet, the list of known solid materials with $\mathrm{Cbl}$ binding properties is limited, and these compounds are not quite adequate to the task. For instance, $\mathrm{H}_{2} \mathrm{O} \cdot \mathrm{Cbl}$ can be adsorbed on amino-Sepharose [6], but the process is slow and requires high concentrations of the ligand. Several other matrices also contain groups with potential affinity for $\mathrm{H}_{2} \mathrm{O} \cdot \mathrm{Cbl}$, e.g. imidazole derivatives or SH-groups [1]. However, they are expected to be either weak binders or prone to side reactions.

In the current publication we present tetrazole derivatives as novel compounds with high affinity for $\mathrm{H}_{2} \mathrm{O} \cdot$ corrinoids $\left(\mathrm{Co}^{3+/ 2+}\right)$. The active groups can be easily created inside a solid material according to the described method [7]. The $\mathrm{Cbl}$ binding properties of the prepared matrix (STZ) were tested under different conditions and argue for a broad applicability of this adsorbent.

\section{Results and discussion}

\subsection{Binding of amino-tetrazole to $\mathrm{H}_{2} \mathrm{O} \cdot \mathrm{Cbl}$}

Incubation of $\mathrm{H}_{2} \mathrm{O} \cdot \mathrm{Cbl}\left(\mathrm{Co}^{3+}\right)$ with amino-tetrazole (ATZ) at $\mathrm{pH} 7.5$ was accompanied by characteristic changes in the absorbance spectrum (Fig. 2a), which were quite similar to those in the mixtures of $\mathrm{H}_{2} \mathrm{O} \cdot \mathrm{Cbl}$ with imidazole or His [8,9]. Kinetics of the reaction ATZ + 

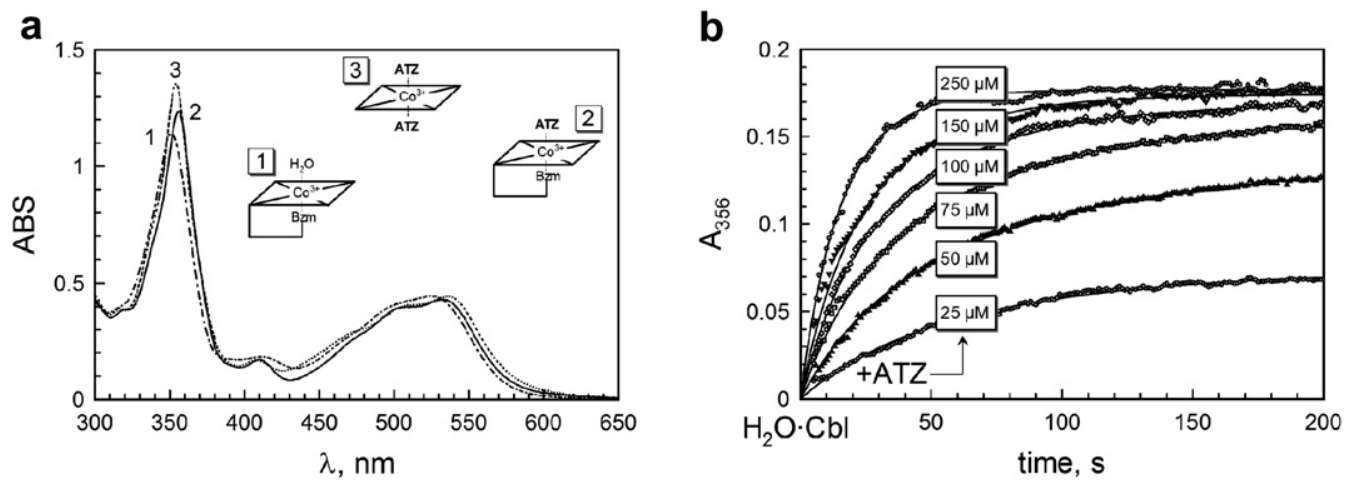

Fig. 2. Change in absorbance spectra upon interactions between $\mathrm{ATZ}$ and aquo-corrinoids. (a) Absorbance spectra of $50 \mu \mathrm{M} \mathrm{H}_{2} \mathrm{O} \cdot \mathrm{Cbl}(1) ; 50 \mu \mathrm{M}$ $\mathrm{H}_{2} \mathrm{O} \cdot \mathrm{Cbl}+2 \mathrm{mM}$ ATZ (2); $50 \mu \mathrm{M}\left[\mathrm{H}_{2} \mathrm{O} \cdot \mathrm{Co}^{3+} \cdot \mathrm{H}_{2} \mathrm{O}\right] \mathrm{Cbi}+2 \mathrm{mM} \mathrm{ATZ}$ (3). Spectra were recorded in $0.2 \mathrm{M} \mathrm{P}_{\mathrm{i}}$-buffer, pH 7.5, $22{ }^{\circ} \mathrm{C}$. (b) Change in $\mathrm{A}_{356}$ followed over time for the reaction $\mathrm{H}_{2} \mathrm{O} \cdot \mathrm{Cbl}(50 \mu \mathrm{M})+\mathrm{ATZ}(25-250 \mu \mathrm{M}), 0.2 \mathrm{M} \mathrm{P}_{\mathrm{i}}$-buffer, $\mathrm{pH} 7.5,37^{\circ} \mathrm{C}$.

$\mathrm{H}_{2} \mathrm{O} \cdot \mathrm{Cbl} \rightleftarrows \mathrm{ATZ} \cdot \mathrm{Cbl}$ was followed over time by monitoring the changes in absorbance at different ATZ concentrations (Fig. 2b). The association rate constant $k_{+\mathrm{ATZ}}$ and the dissociation rate constant $k_{- \text {ATZ }}$ were calculated (Table 1). Since the dissociation stability of $\mathrm{ATZ} \cdot \mathrm{Cbl}$ complex appeared to be quite high $K_{\mathrm{d}} \approx 4 \mu \mathrm{M}\left(20-37{ }^{\circ} \mathrm{C}, \mathrm{pH} 7.5\right.$, $I=0.5 \mathrm{M}$ ), the low affinity amino-group was ruled out as a potential coordinating agent. For example, previous analysis revealed a weak binding of amino acids Asp, Lys, Ser to $\mathrm{H}_{2} \mathrm{O} \cdot \mathrm{Cbl}$ under the same conditions, $K_{\mathrm{d}} \approx 10 \mathrm{mM}$ [9]. Only histidine was a capable ligand due to presence of imidazole group, $K_{\mathrm{d}} \approx 0.24 \mathrm{mM}$ [9]. Therefore, the tetrazole moiety of ATZ was suggested to be the component with high affinity for $\mathrm{H}_{2} \mathrm{O} \cdot \mathrm{Cbl}$ (Fig. 1c).

Nitrogen-containing heterocycles react preferentially with the upper axial position of $\mathrm{Cbl}[1]$, scheme in Fig. 1c. Nevertheless, the external ligand present at high concentration can also displace the Bzm-base and coordinate to the lower position, though with reduced affinity and velocity of the binding (Fig. 1b). This binding model was observed in the reaction between $\mathrm{H}_{2} \mathrm{O} \cdot \mathrm{Cbl}$ and $0.2-$ $1 \mathrm{M}$ imidazole [8], and it cannot be ruled out for ATZ. We did not investigate this subject in further detail, yet the pattern of interaction between $\mathrm{H}_{2} \mathrm{O} \cdot \mathrm{Cbl}$ and the tetrazole-containing matrix supports the model with two coordination positions. As for the baseless corrinoids, they can easily coordinate the external ligands at both axial positions (Fig. 1d). Indeed, an amplified spectral signal was obtained for diaquo-form of Cbi when mixed with ATZ (Fig. 2a).

The ability of the tetrazole derivatives to bind to $\mathrm{H}_{2} \mathrm{O} \cdot \mathrm{Cbl}$ is described for the first time. We made a rough estimate of the binding parameters under various conditions. Thus, the reaction was most efficient at $\mathrm{pH}$ 4-6 and low ionic strength. However, close spectral properties of $\mathrm{H}_{2} \mathrm{O} \cdot \mathrm{Cbl}$ and $\mathrm{ATZ} \cdot \mathrm{Cbl}$ at $\mathrm{pH}<7$ precluded accurate monitoring of the binding reaction (not shown).

\subsection{Preparation of $S T Z$, and kinetics of $\mathrm{H}_{2} \mathrm{O} \cdot \mathrm{Cbl}$ binding}

Attempt to conjugate ATZ via its amino-group to epoxy- or CNBr-activated Sepharose was not particularly successful, and the acquired Cbl-binding capacity did not exceed $0.5-1 \mathrm{mM}$ in the packed matrix. We have therefore changed the strategy. It is known that treatment of organic nitriles with azide is accompanied by formation of tetrazole derivatives, although with different efficiencies [10-12]. The reaction is prompted by the presence of an electron-withdrawing group in close vicinity to nitrile, making the active component of CNBr-activated Sepharose $\mathrm{R}-\mathrm{O}^{\delta-}$ $\mathrm{C}^{\delta+} \equiv \mathrm{N}^{\delta-}$ sufficiently promising. The assumed mechanism of the process is shown in Fig. 3a, yet, variable schemes of cyclization are discussed in the literature $[11,12]$. Incubation of $\mathrm{CNBr}$-activated Sepharose with azide, indeed, led

Table 1

Interaction of $\mathrm{NaN}_{3}, \mathrm{ATZ}$ and $\mathrm{STZ}$ with $\mathrm{H}_{2} \mathrm{O} \cdot \mathrm{Cbl}$

\begin{tabular}{lcccc}
\hline Reacting compound & $k_{+}\left(\mathrm{M}^{-1} \mathrm{~s}^{-1}\right)$ & $k_{-}\left(\mathrm{s}^{-1}\right)$ & $K_{\mathrm{d}}(\mu \mathrm{M})$ & $\mathrm{Conditions} t\left({ }^{\circ} \mathrm{C}\right), \mathrm{pH}, I(\mathrm{M})$ \\
\hline $\mathrm{NaN}_{3}{ }^{\mathrm{a}}$ & $2500 \pm 150$ & $0.13 \pm 0.03$ & $50 \pm 10$ & $37, \mathrm{pH} 7.5, I=0.5$ \\
$\mathrm{ATZ}$ & $310 \pm 20$ & $12 \pm 4 \times 10^{-4}$ & $3.9 \pm 0.7$ & $37, \mathrm{pH} 7.5, I=0.5$ \\
& $90 \pm 10$ & $4 \pm 1 \times 10^{-4}$ & $4.4 \pm 1.1$ & $22, \mathrm{pH} 7.5, I=0.5$ \\
$\mathrm{STZ}$ & $57 \pm 3$ & $6 \pm 1 \times 10^{-4}$ & $10 \pm 2$ & $37, \mathrm{pH} 7.5, I=0.5$ \\
& $20 \pm 2$ & $3 \pm 1 \times 10^{-4}$ & $15 \pm 5$ & $22, \mathrm{pH} 7.5, I=0.5$ \\
& $25 \pm 3$ & $2.2 \pm 0.6 \times 10^{-4}$ & $9 \pm 3$ & $22, \mathrm{pH} 6.0, I=0.5$ \\
& $84 \pm 4$ & $2.0 \pm 0.6 \times 10^{-4}$ & $2.4 \pm 0.7$ & $22, \mathrm{pH} 6.0, I=0.01$ \\
& & Equilibrium $(24 \mathrm{~h})$ & $\approx 0.3$ & $22, \mathrm{pH} 6.0, I=0.5$ \\
& Equilibrium $(24 \mathrm{~h})$ & $22, \mathrm{pH} 6.0, I=0.01$
\end{tabular}

${ }^{\mathrm{a}}$ Data from [9]. 


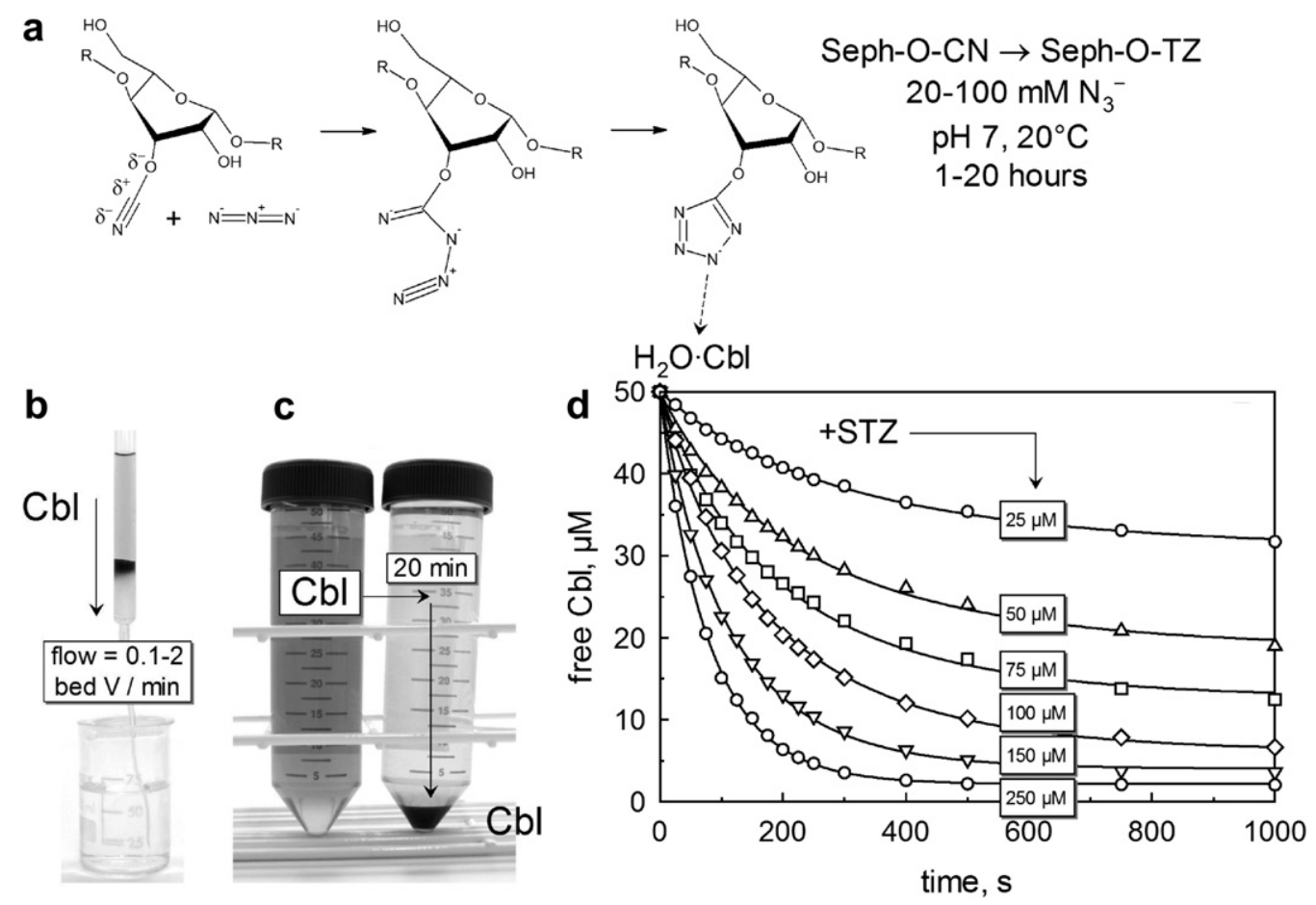

Fig. 3. Adsorption of $\mathrm{H}_{2} \mathrm{O} \cdot \mathrm{Cbl}$ on STZ. (a) Treatment of CNBr-activated Sepharose with azide, and initiation of tetrazole-groups in the matrix. (b) Filtration of $50 \mu \mathrm{M} \mathrm{H}_{2} \mathrm{O} \cdot \mathrm{Cbl}$ through an STZ-column. (c) Batch adsorption of $50 \mu \mathrm{M} \mathrm{H} \mathrm{H}_{2} \mathrm{O} \cdot \mathrm{Cbl}$ on STZ. (d) Kinetics of $\mathrm{H}_{2} \mathrm{O} \cdot \mathrm{Cbl}$ adsorption on STZ at different concentrations of the binding groups, $37^{\circ} \mathrm{C}, \mathrm{pH} 7.5, I=0.5 \mathrm{M}$.

to initiation of $\mathrm{H}_{2} \mathrm{O} \cdot \mathrm{Cbl}$ binding properties in the matrix. Thus, incubation with $20 \mathrm{mM} \mathrm{NaN}_{3}\left(\mathrm{pH} 7-9,22^{\circ} \mathrm{C}\right)$ gave the following concentrations of the binding groups in the packed material: $7 \mathrm{mM}$ (after $1 \mathrm{~h}$ incubation), $8.5 \mathrm{mM}$ $(2 \mathrm{~h}), 9.5 \mathrm{mM}(20 \mathrm{~h})$. Higher concentration of azide $(100 \mathrm{mM})$ was slightly better in terms of velocity: $9 \mathrm{mM}$ $(1 \mathrm{~h}), 10 \mathrm{mM}(20 \mathrm{~h})$. Increased temperature $37-65^{\circ} \mathrm{C}$ accelerated the reaction, so that it was accomplished in 30 $60 \mathrm{~min}$. The maximal concentration of the $\mathrm{H}_{2} \mathrm{O} \cdot \mathrm{Cbl}$ binding groups inside the adsorbent corresponded to $10-12 \mathrm{mM}$ when using fresh $\mathrm{CNBr}$-activated Sepharose.

The prepared Sepharose-tetrazole matrix (STZ) bound $\mathrm{H}_{2} \mathrm{O} \cdot \mathrm{Cbl}$ in both column chromatography (Fig. 3b) and batch adsorption experiments (Fig. 3c). The binding reaction for $\mathrm{STZ}+\mathrm{H}_{2} \mathrm{O} \cdot \mathrm{Cbl} \rightleftarrows \mathrm{STZ} \cdot \mathrm{Cbl}$ was investigated under the same conditions as for ATZ (this publication) and azide [9] for comparative purposes. The process was followed by decrease in the concentration of free $\mathrm{H}_{2} \mathrm{O} \cdot \mathrm{Cbl}$ when incubated in batch at different dilutions of the matrix (Fig. 3d). The calculated rate coefficients showed similarity to ATZ-binding rather than azide-reaction (Table 1) and resulted in $K_{\mathrm{d}} \approx 10 \mu \mathrm{M}$.

\subsection{Binding of $\mathrm{H}_{2} \mathrm{O} \cdot \mathrm{Cbl}$ to $\mathrm{STZ}$ under different conditions}

The binding conditions under the initial tests $\left(0.2 \mathrm{M} \mathrm{P}_{\mathrm{i}^{-}}\right.$ buffer, pH 7.5) were not optimal, see Section 2.1. Therefore, the below experiments address the adsorption of $\mathrm{H}_{2} \mathrm{O} \cdot \mathrm{Cbl}$ on STZ at different $\mathrm{pH}$, ionic strength and temperature. The $\mathrm{pH}$ dependence in Fig. 4a reveals that the binding velocity is influenced by protonation of at least three groups and reaches its maximum at $\mathrm{pH} 4-7$. Two acidic groups are expected to reflect the acid-base equilibria of tetrazole. Protonation of two neighbouring tetrazolegroups with $\mathrm{p} K_{1}=0.6$ and $\mathrm{p} K_{2}=3.6$ seems to be a more probable explanation than a two step protonation of one residue $\mathrm{STZ}^{-} \rightleftarrows \mathrm{STZH} \rightleftarrows \mathrm{STZH}_{2}{ }^{+}$according to the known $\mathrm{p} K$ values of different tetrazole derivatives [13]. The third equilibrium at alkaline $\mathrm{pH}\left(\mathrm{p} K_{3}=8.2\right)$ reflects conversion between aquo- and hydroxo-forms of $\mathrm{Cbl}[1]$, where hydroxide ion has higher affinity for cobalt-ion and hinders coordination of tetrazole.

Equilibration of $\mathrm{STZ}+\mathrm{H}_{2} \mathrm{O} \cdot \mathrm{Cbl}$ suspension over a period of time revealed gradual improvement in the binding strength. Thus, approximately a tenfold decrease in the apparent equilibrium constant $K_{\mathrm{d}}$ was observed after $20 \mathrm{~h}$ of incubation (Fig. 4b). The effect was detected at different concentrations of $\mathrm{NaCl}$ in the mixture and, therefore, could not be ascribed to the presence of a Cblcoordinating contaminant in the salt. The raise in the affinity is likely to be achieved via formation of the additional STZ-Cbl coordination bond, where the second TZ-group substitutes for the Bzm-base of $\mathrm{Cbl}$ as shown in Fig. 4b. The ability of nitrogen-containing heterocycles to displace Bzm from its $\alpha$-position was observed, for example, at high concentrations of imidazole-derivatives [8]. The estimated value of dissociation constant after complete equilibration of the STZ-Cbl suspension was less than $1 \mu \mathrm{M}$.

The data in Fig. 4b also suggest importance of ionic strength for the affinity. Therefore, the dependencies of 

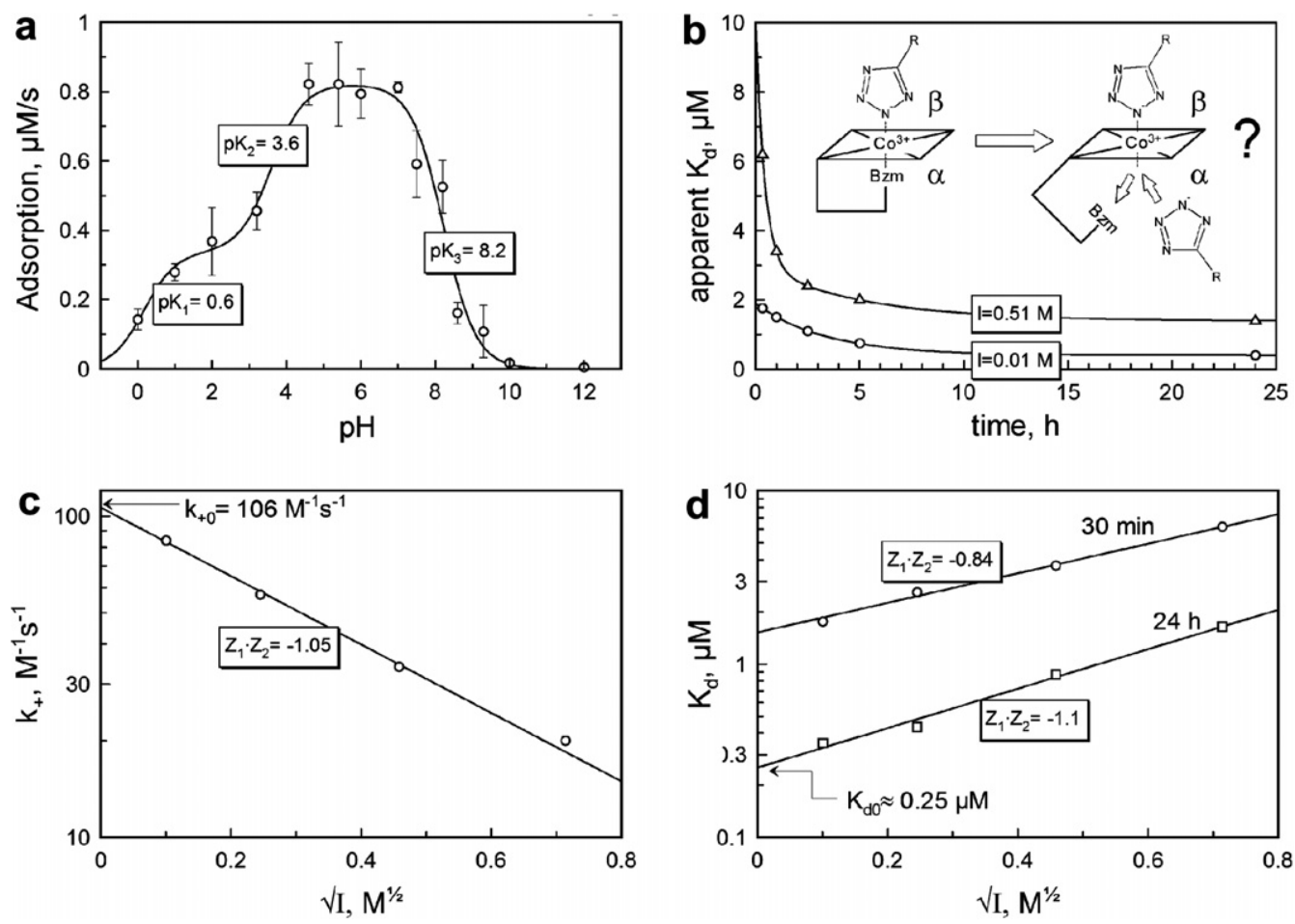

Fig. 4. Interaction between $\mathrm{H}_{2} \mathrm{O} \cdot \mathrm{Cbl}$ and $\mathrm{STZ}$ under different conditions. (a) Velocity of the binding reaction $\mathrm{H}_{2} \mathrm{O} \cdot \mathrm{Cbl}+\mathrm{STZ}$ as function of pH: $\mathrm{Cbl}=30 \mu \mathrm{M}, \quad \mathrm{STZ}=400 \mu \mathrm{M}, 0.1 \mathrm{M}$ phosphate, acetate and carbonate buffers, $22{ }^{\circ} \mathrm{C}$. (b) Change of the apparent dissociation constant $\left(\mathrm{STZ}+\mathrm{H}_{2} \mathrm{O} \cdot \mathrm{Cbl} \rightleftarrows \mathrm{STZ} \cdot \mathrm{Cbl}\right)$ over time: $0.01 \mathrm{M} \mathrm{P} \mathrm{P}_{\mathrm{i}}$-buffer, $\mathrm{pH} 6.0, \pm 0.5 \mathrm{M} \mathrm{NaCl}, 22{ }^{\circ} \mathrm{C}$. (c) Dependence of the attachment rate constant $\left(\mathrm{STZ}+\mathrm{H}_{2} \mathrm{O} \cdot \mathrm{Cbl} \rightarrow\right)$ on ionic strength: $0.01 \mathrm{M} \mathrm{P} \mathrm{P}_{\mathrm{i}}$-buffer, $\mathrm{pH} 6.0,+0.0 / 0.05 / 0.2 / 0.5 \mathrm{M} \mathrm{NaCl}, 22^{\circ} \mathrm{C}$. Data were fitted according to the equation $\lg \left(k_{+}\right)=\lg \left(k_{0}\right)+0.509 \cdot Z_{1} \cdot Z_{2} \cdot \sqrt{I}$. (d) Dependence of the apparent dissociation constant on ionic strength, conditions as in panel C. Measurements were conducted after $30 \mathrm{~min}$ and $24 \mathrm{~h}$ of incubation. Data were fitted according to the equation $\lg \left(K_{\mathrm{d}}\right)=\lg \left(K_{0}\right)-0.509 \cdot Z_{1} \cdot Z_{2} \cdot \sqrt{I}$.

the attachment rate constant $k_{+}$and the apparent equilibrium dissociation constant $K_{\mathrm{d}}$ on $I^{1 / 2}$ were analysed according to the Debye-Hückel's limited law (Fig. 4c and d). Fit of both data sets resulted in the charge product for the interacting molecules $\left(Z_{1} \cdot Z_{2}\right)$ close to $-1(\mathrm{pH} 6$, $22^{\circ} \mathrm{C}$ ). This result corroborates the values of $Z_{\mathrm{Cbl}} \approx+1$ and $Z_{\mathrm{TZ}} \approx-1$, expected under the experimental conditions ( $\mathrm{pH}$ 6). Extrapolation to $I=0 \mathrm{M}$ gave $k_{+0} \approx 100 \mathrm{M}^{-1} \mathrm{~s}^{-1}$ for the forward reaction, and $K_{\mathrm{d} 0} \approx 0.25 \mu \mathrm{M}$ for the equilibrated sample (Fig. $4 \mathrm{c}$ and $\mathrm{d}$ ).

Change of the temperature from $22^{\circ} \mathrm{C}$ to $37^{\circ} \mathrm{C}$ increased velocity of $\mathrm{H}_{2} \mathrm{O} \cdot \mathrm{Cbl}$ adsorption (Table 1), and the ratio between two rate coefficients $k_{+(37)} / k_{+(22)} \approx 3$ corresponded to the activation energy of $E_{\mathrm{a}} \approx 56 \mathrm{~kJ} \mathrm{~mol}^{-1}$. However, the affinity was hardly affected, at least inside the above range of temperature (Table 1).

The performed analysis allowed us to evaluate the velocity of adsorption when a solution of $\mathrm{H}_{2} \mathrm{O} \cdot \mathrm{Cbl}$ is filtered through a packed column with approximately $10 \mathrm{mM}$ concentration of the binding groups. Under the optimal conditions ( $\mathrm{pH} 4-7, I \approx 0$ ) one can expect $>99 \%$ binding of the ligand in $10 \mathrm{~s}\left(22^{\circ} \mathrm{C}\right)$. At higher ionic strength $(I \approx 0.5 \mathrm{M})$ this time increases to $50 \mathrm{~s}$. Change of temperature from $22^{\circ} \mathrm{C}$ to $50^{\circ} \mathrm{C}$ would accelerate the binding by factor $\approx 8$, whereas at $5{ }^{\circ} \mathrm{C}$ the adsorption velocity would be four-fold slower than at $22^{\circ} \mathrm{C}$.

\subsection{Interaction of different corrinoids with $S T Z$}

We have tested interaction of different corrinoids with STZ. The highest affinity was detected for diaquo-form of cobinamide $\left[\mathrm{H}_{2} \mathrm{O} \cdot \mathrm{Co}^{3+} \cdot \mathrm{H}_{2} \mathrm{O}\right] \mathrm{Cbi}\left(K_{\mathrm{d}}<0.1 \mu \mathrm{M}\right.$ at $\mathrm{pH}$ $6, I=0.01-0.2 \mathrm{M})$. Yet, velocity of its attachment was not higher than that for $\mathrm{H}_{2} \mathrm{O} \cdot \mathrm{Cbl}$, clearly indicating slower dissociation of STZ-Cbi complex. Coordination of two TZ-groups at the upper and lower surfaces of $\mathrm{Cbi}$ may account for better retention of this baseless ligand (Fig. 1d). The matrix also bound a number of other aquo-corrinoids: $\quad\left[\mathrm{CN} \cdot \mathrm{Co}^{3+} \cdot \mathrm{H}_{2} \mathrm{O}\right] \mathrm{Cbi}, \quad\left[\mathrm{H}_{2} \mathrm{O} \cdot \mathrm{Co}^{3+}\right]-$ pseudo- $\mathrm{B}_{12},\left[\mathrm{H}_{2} \mathrm{O} \cdot \mathrm{Co}^{3+}\right]$-factor $\mathrm{A}$, as well as the reduced forms $\left[\mathrm{Co}^{2+}\right] \mathrm{Cbi}$ and $\left[\mathrm{Co}^{2+}\right] \mathrm{Cbl}$. Parameters of these reactions were not investigated in details, yet, the column adsorption of the mentioned analogues seemed to be as efficient as that of $\mathrm{H}_{2} \mathrm{O} \cdot \mathrm{Cbl}$.

In contrast to the above Cbl-analogues, there was practically no interaction between STZ and the corrinoids with protected corrin ring, e.g. $\mathrm{CN} \cdot \mathrm{Cbl},\left[\mathrm{CN} \cdot \mathrm{Co}^{3+} \cdot \mathrm{CN}\right] \mathrm{Cbi}$, adenosyl-forms of $\mathrm{Cbl} /$ pseudo- $\mathrm{B}_{12} /$ factor $\mathrm{A}$. The two latter substances presented an interesting example of trans-axial effect, where the ligand coordinated to one side of the ring affected interactions at the opposite side via the cobalt ion. It is known that the efficient donation of electrons from the upper Ado-group to the Co-ion causes detachment of the nucleotide base from the lower surface of pseudo- $\mathrm{B}_{12}$ and 
factor A $[2,14]$. It seems that the binding of tetrazole in place of the dissociated nucleotide was also precluded.

Apart from the above groups with high affinity for the cobalt-ion, the axial compounds with moderate binding strength could also negatively affect STZ $+\mathrm{Cbl}$ interactions. The group of adverse effectors includes, for example, $1 \mathrm{mM}$ glutathione (GSH), $10 \mathrm{mM}$ imidazole, $1 \mathrm{mM}$ azide, $100 \mathrm{mM} \mathrm{NH}_{4} \mathrm{OH}, \mathrm{pH} \approx 11$. Several binding curves for protected corrinoids are presented in Fig. 5a.

\subsection{De-blocking of the $\beta$-protected $\mathrm{Cbl}$}

Depending on the properties of the protecting group, de-blocking of the $\beta$-site can be done in different ways, and below we mention several general approaches to the problem (Fig. 5b). The most resistant axial ligand is cyanide, and conversion of $\mathrm{CN} \cdot \mathrm{Cbl}$ to $\mathrm{H}_{2} \mathrm{O} \cdot \mathrm{Cbl}$ requires chemical or electrochemical reduction followed by oxidation in aqueous solution [1,2]. The carbon-cobalt bond of the two natural organo-cobalamins $\mathrm{Ado} \cdot \mathrm{Cbl}$ and $\mathrm{Me} \cdot \mathrm{Cbl}$ is sensitive to light, and illumination of the sample for 15 $30 \mathrm{~min}$ in aerated solution would produce $\mathrm{H}_{2} \mathrm{O} \cdot \mathrm{Cbl}[1,9]$. The same is also valid for other organo-corrinoids.

Many axial ligands with moderate affinity for the corrin ring can be dissociated at low $\mathrm{pH}$, because they essentially lose Cbl-binding properties after protonation, e.g. $\mathrm{GS} \cdot \mathrm{Cbl} \rightleftarrows \mathrm{GS}^{-}+\mathrm{Cbl} \rightleftarrows \mathrm{GSH}+\mathrm{Cbl}$. Application of other de-blocking agents is also possible. For instance, dissociation of glutathione is facilitated by $\mathrm{Cu}^{2+}$ due to the complexation reaction $\mathrm{GS}^{-}+\mathrm{Cu}^{2+} \rightleftarrows \mathrm{Cu}(\mathrm{GS})_{2}$. This effect was observed at $1 \mathrm{mM} \mathrm{GSH}$ in the presence of $2 \mathrm{mM}$ $\mathrm{CuSO}_{4}, \mathrm{pH} 3-4$. As a universal approach to the specific binding of $\mathrm{H}_{2} \mathrm{O} \cdot \mathrm{Cbl}$ from various solutions with hindering compounds we can suggest adsorption on the $\mathrm{STZ}$ at $\mathrm{pH}$ $3-4$. These conditions are not optimal, however the column filtration at a reduced flow (0.1-0.2 bed volume per minute) makes adsorption of $\mathrm{H}_{2} \mathrm{O} \cdot \mathrm{Cbl}$ quite efficient. All the mentioned methods of Cbl-reactivation are schematically depicted in Fig. 5b.

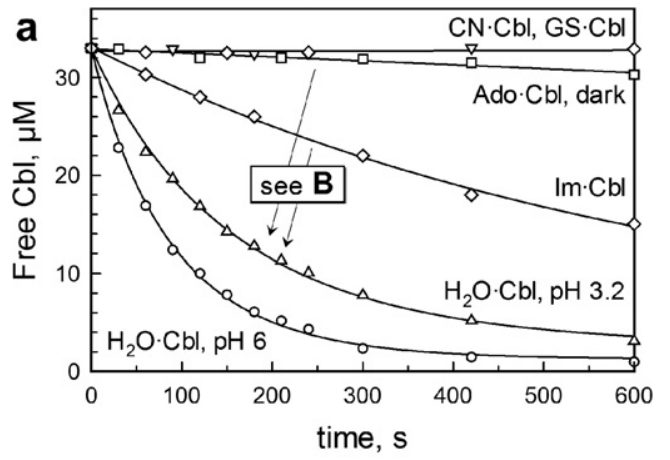

\subsection{Other hindering compounds}

Cbl binding proteins with high affinity for the ligand belong to the group of substances, which affect $\mathrm{H}_{2} \mathrm{O} \cdot \mathrm{Cbl}$ adsorption on STZ $[3,9,15,16]$. Thus, attachment of $\mathrm{H}_{2} \mathrm{O} \cdot \mathrm{Cbl}$ to the specific transporting proteins or enzymes precluded any interaction with the matrix. Most proteins can be however denatured by heating at $85-90^{\circ} \mathrm{C}, \mathrm{pH}$ $3.5,15 \mathrm{~min}$.

Transition metal ions $\mathrm{M}^{2+}\left(\mathrm{Mn}^{2+}, \mathrm{Co}^{2+}, \mathrm{Ni}^{2+}, \mathrm{Cu}^{2+}\right.$, $\mathrm{Zn}^{2+}$ ) can potentially decrease affinity of STZ for $\mathrm{H}_{2} \mathrm{O} \cdot \mathrm{Cbl}$ by direct coordination to the tetrazole groups $\mathrm{STZ} \cdot \mathrm{M}^{2+}$ [17]. Indeed, presence of $1 \mathrm{mM} \mathrm{CuSO}_{4}$ in the medium $(\mathrm{pH} 3.5)$ decreased velocity of the binding $\mathrm{H}_{2} \mathrm{O} \cdot \mathrm{Cbl}+\mathrm{STZ}$ by factor 5 (not shown). However, the mentioned ions $\left(\mathrm{M}^{2+}\right)$ can be removed from the solution by adjustment of $\mathrm{pH}>7$ and precipitation of the insoluble metal hydroxide $\mathrm{M}(\mathrm{OH})_{2}$.

\subsection{Elution of the bound corrinoids from $S T Z$}

Retention of the adsorbed $\mathrm{Cbl}$ by STZ at $\mathrm{pH} 4-7$ was very efficient if the saturation level was below $80 \%$. Thus, no significant leakage of the ligand was detected during the column washing using solutions with different ionic strength $(0.01-2 \mathrm{M})$ and temperature $\left(20-65^{\circ} \mathrm{C}\right)$. However, a progressively increasing desorption was observed at higher degree of saturation (80-100\%).

Liberation of $\mathrm{Cbl}$ from the affinity adsorbent can be carried out in several ways depending on the purpose of the work. Batch mode (STZ:eluent $=1: 10$ ), when using a warm alkaline buffer with added $\mathrm{KCN}$ (e.g. $\mathrm{pH} 12$, $\mathrm{KCN}=10 \mathrm{mM}, 95^{\circ} \mathrm{C}, 5-10 \mathrm{~min}$ ), results in fast and quantitative elution of $\mathrm{Cbl}$ in its dicyano-form. As high temperature at $\mathrm{pH} 12$ can adversely influence chemical stability of Sepharose, we recommend the above method only for the analytical purposes, e.g. measurement of the titer of the active TZ-groups (see Section 4). Usage of lower temperatures is gentler to the matrix and allows its repeated appli-

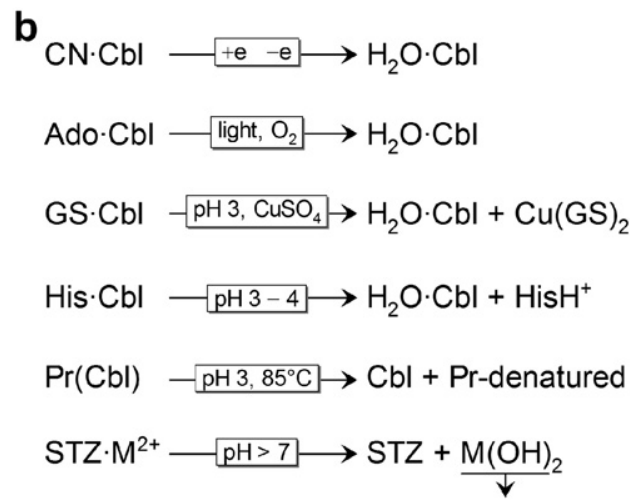

Fig. 5. Hindering effect of different compounds on the binding of $\mathrm{Cbl}$ to STZ. (a) Adsorption curves for different cobalamins: $\mathrm{H}_{2} \mathrm{O} \cdot \mathrm{Cbl}$; $\mathrm{Im} \cdot \mathrm{Cbl}$ $\left(\mathrm{H}_{2} \mathrm{O} \cdot \mathrm{Cbl}+10 \mathrm{mM}\right.$ imidazole); Ado $\cdot \mathrm{Cbl} ; \mathrm{CN} \cdot \mathrm{Cbl}$; GS $\cdot \mathrm{Cbl}\left(\mathrm{H}_{2} \mathrm{O} \cdot \mathrm{Cbl}+1 \mathrm{mM} \mathrm{GSH}\right) ; 0.01 \mathrm{M} \mathrm{P}_{\mathrm{i}}$-buffer, pH 6, $22^{\circ} \mathrm{C}$. (b) Conversion of the STZ-inert cobalamins to $\mathrm{H}_{2} \mathrm{O} \cdot \mathrm{Cbl}$. Notation: $\mathrm{CN} / \mathrm{Ado} / \mathrm{GS} / \mathrm{His} \cdot \mathrm{Cbl}$ correspond to cyano-/adenosyl-/glutathionyl-/histidine-forms of $\mathrm{Cbl}$; $\mathrm{Pr}(\mathrm{Cbl}) \mathrm{represents}$ protein-bound $\mathrm{Cbl}$; $\mathrm{STZ} \cdot \mathrm{M}^{2+}$ is a complex between the tetrazole matrix and a transition metal ion. 
cation. For example, $98-100 \%$ liberation of dicyano-Cb1 could be achieved at room temperature after $5-10 \mathrm{~h}$ of incubation in $10 \mathrm{mM} \mathrm{KCN}, \mathrm{pH} 9-12$. If necessary, dicyano-Cbl can be converted to mono-cyano form $\mathrm{CN} \cdot \mathrm{Cbl}$ by acidification of the medium to $\mathrm{pH}<4$ or removal of excessive cyanide.

Desorption from an STZ-column required longer time of incubation $\left(20-40 \mathrm{~h}, 20-25^{\circ} \mathrm{C}\right)$ and higher concentrations of eluent (e.g. $20 \mathrm{mM} \mathrm{KCN}, 0.1 \mathrm{M} \mathrm{P} \mathrm{P}_{\mathrm{i}}$-buffer, pH 12) when compared with batch elution. One change of the eluent in the column was required after $10-20 \mathrm{~h}$ to guarantee $\approx 95 \%$ liberation of the bound $\mathrm{Cbl}$ in its dicyano-form. Elution at lower $\mathrm{pH}$ was also possible (8-9), but with decreased efficiency of desorption. For example, 2-3 changes of the medium were required at $\mathrm{pH} 9$ to reach the same yield as at $\mathrm{pH} 12$. Other corrinoids can be liberated in similar way. Desalting of the obtained preparations can be done on XAD or charcoal, see Section 4. The final product would be $\mathrm{CN} \cdot \mathrm{Cbl}$.

Two alternative methods of elution are based on $\mathrm{pH}-$ properties of the binding material, where acidic or alkaline medium hampers the binding (Fig. 4a). Thus, $\mathrm{H}_{2} \mathrm{O} \cdot \mathrm{Cbl}$ can be eluted from a column in 10 min using 2-3 bed volumes of $1 \mathrm{M} \mathrm{HCl}$ at continuous flow. The collected sample should be neutralized to minimize slow hydrolysis of the amide side chains in the strong acid [1]. Desorption in an alkaline medium (e.g. $0.1 \mathrm{M} \mathrm{NaOH}$ ) was slower (10-20 h) and required one change of the solution. The product $(\mathrm{HO} \cdot \mathrm{Cbl})$ contained $10-20 \%$ of contaminations which could originate from either selfreduction of $\mathrm{HO} \cdot \mathrm{Cbl}$ in alkaline medium or displacement of $\mathrm{HO}^{-}$from the $\beta$-site by some other compounds [1]. This subject was not investigated further. It should be emphasized that the $\mathrm{pH}$-based methods were inefficient in elution of the baseless analogue $\left[\mathrm{H}_{2} \mathrm{O} \cdot \mathrm{Co}^{3+} \cdot \mathrm{H}_{2} \mathrm{O}\right] \mathrm{Cbi}$ where both axial position seemed to be occupied by the tetrazole groups of STZ (Fig. 1d). Therefore, $\mathrm{H}_{2} \mathrm{O} \cdot \mathrm{Cbl}$ and $\left[\mathrm{H}_{2} \mathrm{O} \cdot \mathrm{Co}^{3+} \cdot \mathrm{H}_{2} \mathrm{O}\right] \mathrm{Cbi}$ could be separated by adsorption on STZ-column and sequential elution with (i) $1 \mathrm{M}$ $\mathrm{HCl}\left(\mathrm{H}_{2} \mathrm{O} \cdot \mathrm{Cbl}\right)$; and (ii) $20 \mathrm{mM} \mathrm{KCN}, \mathrm{pH} 12$ (dicyanoCbi).

\subsection{Chemical and physical stability of the STZ}

The chemical and physical stability of the adsorbent was sufficiently high. Thus, no deterioration of the binding properties was observed after a year of incubation in water at room temperature or after several months in $0.1 \mathrm{M} \mathrm{P}_{\mathrm{i}}$-buffer, $\mathrm{pH} 12,10 \mathrm{mM} \mathrm{KCN}$. Neither $1 \mathrm{M} \mathrm{HCl}$ nor $0.1 \mathrm{M} \mathrm{NaOH}$ immediately affected the $\mathrm{Cbl}$ binding properties of the material. However, physical stability of the matrix against pressure was noticeably deteriorated under strong alkaline conditions, and the Sepharose particles could be easily mashed in $0.1 \mathrm{M} \mathrm{NaOH}$ under gravity forces, e.g. in a column of $50 \mathrm{~cm}$ height. Prolonged incubation of STZ in acid gradually decreased the Cbl-binding capacity of the material, and after $50 \mathrm{~h}$ of incubation in $1 \mathrm{M} \mathrm{HCl}$ the maximal saturation of STZ drops by 30\%. No such effect was found for $0.1 \mathrm{M} \mathrm{NaOH}$, where two months incubation in a column of $2 \mathrm{~cm}$ height did not decrease the level of $\mathrm{Cbl}$ adsorption.

\subsection{Purification of Cbl from a crude mixture}

We tested application of the STZ on a fermentation broth provided by a manufacturer of vitamin $B_{12}$. A standard acidic extraction of $\mathrm{Cbl}$ from cells was conducted in the absence of cyanide. The binding from extract was conducted under suboptimal conditions $(\mathrm{pH}$ 3.7) since the contaminating substances (possibly reduced glutathione) precluded coordination of $\mathrm{Cbl}$ to STZ at $\mathrm{pH}$ 6. Adsorption was conducted in two cycles, preceded by illumination of the extract. Approximately $70 \%$ and $20 \%$ of the total $\mathrm{Cbl}$ was adsorbed from the medium after the first and second passages, respectively. The levels of the bound $\mathrm{Cbl}$ were independent of the flow rate at $v=1-6$ bed volumes per hour. On the contrary, the illumination of the sample was critical, since only $30 \%$ of $\mathrm{Cbl}$ was adsorbed after the first filtration in darkness. Finally, the column material was saturated with $\mathrm{Cbl}$ to the level of 7-8 $\mathrm{mM}$ in the packed matrix. The succeeding purification procedure included following steps: (1) washing with $0.5 \mathrm{NaCl}$ and water; (2) elution with cyanide at alkaline $\mathrm{pH}$; (3) desalting on either XAD or charcoal. The latter procedure removed also excess of cyanide and converted dicyano- $\mathrm{Cbl}$ to $\mathrm{CN} \cdot \mathrm{Cbl}$. The absorbance spectrum of the final preparation in water was indistinguishable from that of commercial $\mathrm{CN} \cdot \mathrm{Cbl}$, and HPLC analysis pointed to $>90 \%$ purity of the sample. The final yield corresponded to $80 \%$ of $\mathrm{Cbl}$ present in the original fermentation broth.

\subsection{Application of STZ for measurement of Cbl-binding capacity and dissociation kinetics}

Association of $\mathrm{H}_{2} \mathrm{O} \cdot \mathrm{Cbl}$ with proteins hinders adsorption on STZ. This property can be advantageously used to measure the $\mathrm{Cbl}$ binding capacity of such protein by spectral method. Firstly, the protein should be saturated with some excess of $\mathrm{H}_{2} \mathrm{O} \cdot \mathrm{Cbl}$, whereupon the unbound ligand should be removed by adsorption on STZ. Finally, the absorbance spectrum of the protein-bound $\mathrm{Cbl}$ can be measured and used to calculate concentration of this complex. Details of this approach are described elsewhere [15].

Ability of STZ to remove free $\mathrm{H}_{2} \mathrm{O} \cdot \mathrm{Cbl}$ from soluble phase can be used to study dissociation kinetics of different complexes, where $\mathrm{H}_{2} \mathrm{O} \cdot \mathrm{Cbl}$ is bound to natural or synthetic compounds with moderate affinity, e.g. the fragments of intrinsic factor [15]. In these experiments, excess of the TZ-groups caused gradual dissociation of $\mathrm{H}_{2} \mathrm{O} \cdot \mathrm{Cbl}$-fragment complexes and allowed us to measure the corresponding rate constants [15]. 


\section{Conclusions}

A simple treatment of CNBr-activated Sepharose with azide produces the matrix with $10 \mathrm{mM}$ concentration of the active groups (presumably tetrazole), which have high affinity and specificity for aquo-corrinoids. Efficient binding can be conducted in a broad range of $\mathrm{pH}$, ionic strength and temperature. Adsorption from a crude cell extract is also possible. Presence of certain contaminants hampers the binding, yet, the effect can be neutralized by changing conditions of adsorption. The novel material is applicable for purification and separation of different corrinoids, as well as for analytical purposes, e.g. investigation of protein-corrinoid interactions. At the same time, the soft Sepharose-based adsorbent does not seem to be adequate for industrial purposes. As an alternative, a robust Cbl-specific polymer could be synthesized, where nitrile-containing monomeric compounds are treated with azide and afterwards polymerized.

\section{Experimental}

\subsection{Materials}

All salts and simple organic materials were from SigmaAldrich and Merck. Cobalamins $\mathrm{H}_{2} \mathrm{O} \cdot \mathrm{Cbl}, \mathrm{CN} \cdot \mathrm{Cbl}$, Ado $\cdot \mathrm{CB}$, dicyano-Cbi were from Sigma-Aldrich. Adoforms of pseudo- $\mathrm{B}_{12}$ and factor $\mathrm{A}$ were kindly provided by Prof. B. Kräutler [14]. Conversion of pseudo- $B_{12}$ and factor A to their aquo-forms was performed by illumination (60 W lamp, $10 \mathrm{~cm}$ distance, $10 \mathrm{~min}$ ). Cobinamides [CN - $\left.\mathrm{Co}^{3+} \cdot \mathrm{H}_{2} \mathrm{O}\right] \mathrm{Cbi}$ and $\left[\mathrm{H}_{2} \mathrm{O} \cdot \mathrm{Co}^{3+} \cdot \mathrm{H}_{2} \mathrm{O}\right] \mathrm{Cbi}$ were synthesized from $\mathrm{CN} \cdot \mathrm{Cbl}$ and $\mathrm{H}_{2} \mathrm{O} \cdot \mathrm{Cbl}$, respectively [18]. Reduced forms $\left[\mathrm{Co}^{2+}\right]$ of $\mathrm{Cbl}$ and $\mathrm{Cbi}$ were obtained from $\left[\mathrm{H}_{2} \mathrm{O} \cdot \mathrm{Co}^{3+}\right] \mathrm{Cbl}$ and $\left[\mathrm{H}_{2} \mathrm{O} \cdot \mathrm{Co}^{3+} \cdot \mathrm{H}_{2} \mathrm{O}\right] \mathrm{Cbi}$, respectively, by treating them with $15 \%$ formaldehyde, $5 \mathrm{~min}, 95^{\circ} \mathrm{C}$.

\subsection{Kinetics of interaction between $\mathrm{ATZ}$ and $\mathrm{H}_{2} \mathrm{O} \cdot \mathrm{Cbl}$}

Solution of $50 \mu \mathrm{M} \mathrm{H} \mathrm{H}_{2} \mathrm{O} \cdot \mathrm{Cbl}$ in $0.2 \mathrm{M} \mathrm{P}_{\mathrm{i}}$-buffer, $\mathrm{pH} 7.5$ $\left(22^{\circ} \mathrm{C}\right.$ or $37^{\circ} \mathrm{C}$ ) was mixed with different concentrations of $\mathrm{ATZ}=25-250 \mu \mathrm{M}$, whereupon change in absorbance was followed at $356 \mathrm{~nm}$. Caution: any contacts between ATZ and metals (including Hamilton Microliter syringes) must be avoided. The recorded curves in Fig. 2b were analysed by appropriate equations of reversible kinetics $\mathrm{A}+\mathrm{B} \rightleftarrows \mathrm{C}$ as explained elsewhere [15].

\subsection{Preparation of $S T Z$}

Both Sepharose 4B (Amersham) activated by $\mathrm{CNBr}$ under laboratory conditions and the commercially available equivalent product (Amersham) can be used for the preparation of the $\mathrm{Cbl}$ binding matrix. Laboratory treatment of Sepharose with CNBr resulted in $30-50 \%$ higher level of the binding groups and was essentially cheaper. The procedure is presented below.
Hundred milliliter of Sepharose 4B Fast Flow was placed into an open thick column $(d=5 \mathrm{~cm}, h=40 \mathrm{~cm})$ capable of fast flow filtration. The matrix was washed with $400 \mathrm{~mL}$ water and $200 \mathrm{~mL}$ of $2 \mathrm{M} \mathrm{K}_{2} \mathrm{HPO}_{4} / \mathrm{K}_{3} \mathrm{PO}_{4}, \mathrm{pH} 11$, until no liquid remained above the packed Sepharose. The flow was stopped, the column was placed into a fume hood, and $100 \mathrm{~mL}$ of $2 \mathrm{M}$ phosphate buffer, $\mathrm{pH} 11$, was added to $100 \mathrm{~mL}$ of Sepharose to make slurry 1:1. The reaction was started by adding freshly prepared $10 \% \mathrm{CNBr}$ dissolved in $250 \mathrm{~mL} \mathrm{H}_{2} \mathrm{O}$ at $40-50{ }^{\circ} \mathrm{C}$ and cooled to room temperature. The $\mathrm{CNBr}$ solution $\left(22^{\circ} \mathrm{C}\right)$ was added to the Sepharose suspension in three portions at $0,1,2$ min of the reaction under continuous mixing. The process was carried on for another $3 \mathrm{~min}$ while $\mathrm{pH}$ fell to $\mathrm{pH} 8$. Then, the reaction suspension was drained (2-3 min), and the $\mathrm{CNBr}$-activated Sepharose was washed with $100 \mathrm{~mL}$ of $0.1 \mathrm{M} \mathrm{P}_{\mathrm{i}}$-buffer, $\mathrm{pH}$ 7.5; $500 \mathrm{~mL} \mathrm{H} \mathrm{H}_{2} \mathrm{O}$; and again $100 \mathrm{~mL}$ of $\mathrm{P}_{\mathrm{i}}$-buffer. The flow was stopped when no liquid remained above the packed matrix. Immediately afterwards the prepared material was interacted with azide to produce STZ.

Reaction between the nitrile groups of Sepharose and azide was started by adding $100 \mathrm{~mL}$ of $100 \mathrm{mM} \mathrm{NaN}_{3}$ dissolved in $0.1 \mathrm{M} \mathrm{P}_{\mathrm{i}}$-buffer, $\mathrm{pH} 7.5$ (50 mM final concentration of $\mathrm{NaN}_{3}$ in the slurry). The suspension was periodically agitated for the first $30 \mathrm{~min}$ and left either overnight at $22^{\circ} \mathrm{C}$ or for $3-4 \mathrm{~h}$ at $37^{\circ} \mathrm{C}$. Next day STZ was washed with $200 \mathrm{~mL}$ of $0.1 \mathrm{M}$ Pottassium-phosphate buffer, $\mathrm{pH}$ $11.5-12$, and incubated either overnight at $22^{\circ} \mathrm{C}$ or for $3-$ $4 \mathrm{~h}$ at $37^{\circ} \mathrm{C}$. The latter alkaline treatment increased the amount of Cbl-binding groups by $50-70 \%$. Finally, the prepared material was washed with $1 \mathrm{~L}$ of $\mathrm{H}_{2} \mathrm{O}$, and a slurry $\mathrm{STZ}: \mathrm{H}_{2} \mathrm{O}=1: 1$ was prepared. STZ can be stored both at room temperature and at $5{ }^{\circ} \mathrm{C}$ at least for a year without any deterioration of the Cbl-binding properties.

If commercially available CNBr-activated Sepharose 4B is used for preparation of STZ, it should be extensively washed for 15-20 min with $1 \mathrm{mM} \mathrm{HCl}$ and then equilibrated with a neutral solution of $50 \mathrm{mM} \mathrm{NaN}_{3}$ as described in the above paragraph.

\subsection{Measurement of the active groups in STZ}

$0.05 \mathrm{ml}$ of the suspension STZ:water (1:1) was mixed with $0.5 \mathrm{ml}$ of $1 \mathrm{mM} \mathrm{Cbl-}-\mathrm{OH}_{2}$ in $0.01 \mathrm{M} \mathrm{P}_{\mathrm{i}}$-buffer, $\mathrm{pH} 6$ and incubated for $5 \mathrm{~min}$. The sample was centrifuged $(10000 \mathrm{rpm}, 30 \mathrm{~s})$, the supernatant was discarded, and the coloured pellet was washed with $2 \mathrm{ml}$ of $0.1 \mathrm{M} \mathrm{P}_{\mathrm{i}}$-buffer, $\mathrm{pH} 6$ for $1 \mathrm{~min}$. The adsorbent was collected by brief centrifugation, and the bound $\mathrm{Cbl}$ was eluted in 5 min under the following conditions: $2 \mathrm{ml}$ of $2 \mathrm{mM} \mathrm{KCN}, 0.1$ $\mathrm{K}_{2} \mathrm{HPO}_{4} / \mathrm{K}_{3} \mathrm{PO}_{4}$ buffer, $\mathrm{pH} 12,95^{\circ} \mathrm{C}$. The concentration of the eluted dicyano-Cbl was measured in the supernatant according to the following absorbance coefficients, $\varepsilon_{367}=30400, \varepsilon_{579}=9900 \mathrm{M}^{-1} \mathrm{~cm}^{-1}$. The concentration of the Cbl-binding groups in the original STZ $(25 \mu \mathrm{L})$ is expected to be $8-12 \mathrm{mM}$, which corresponds to $4-6 \mathrm{mM}$ in the slurry STZ: water $=1: 1$. 


\subsection{Kinetics of interaction between $\mathrm{STZ}$ and $\mathrm{H}_{2} \mathrm{O} \cdot \mathrm{Cbl}$}

Solutions of $50 \mu \mathrm{M} \mathrm{H}_{2} \mathrm{O} \cdot \mathrm{Cbl}$ in $0.2 \mathrm{M} \mathrm{P}_{\mathrm{i}}$-buffer, $\mathrm{pH} 7.5$ $\left(22^{\circ} \mathrm{C}\right.$ or $\left.37^{\circ} \mathrm{C}\right)$ were mixed with different amounts of STZ, e.g. a $10 \mathrm{~mL}$ sample plus $0.050-0.5 \mathrm{~mL}$ suspension of STZ:water (1:1), final concentration of $\mathrm{STZ}=25$ $250 \mu \mathrm{M}$. The prepared mixtures were incubated with slight agitation, and $0.5 \mathrm{ml}$ fractions were filtered under pressure after different time intervals. The concentration of remaining $\mathrm{H}_{2} \mathrm{O} \cdot \mathrm{Cbl}$ in the filtrates was measured $\left(\varepsilon_{352}=23200 \mathrm{M}^{-1} \mathrm{~cm}^{-1}\right)$ and plotted over time (Fig. 3a). Analysis of bimolecular binding kinetics was performed as described elsewhere [15].

The binding experiments for STZ plus an aquo-corrinoid ( $\mathrm{Cbl}, \mathrm{Cbi}$, pseudo- $\mathrm{B}_{12}$, factor $\left.\mathrm{A}\right)$ were conducted in similar way at varying $\mathrm{pH}$, ionic strength and temperature. The following absorbance coefficients $\left(\mathrm{M}^{-1} \mathrm{~cm}^{-1}\right)$ were used for $\mathrm{H}_{2} \mathrm{O} \cdot \mathrm{Cbl}: \varepsilon_{351}=26200(\mathrm{pH} 2-5) ; \varepsilon_{352}=23200$ (pH 7.5); $\varepsilon_{358}=20500$ (pH 10-12).

An apparent equilibrium dissociation constant for the reaction $\mathrm{STZ}+\mathrm{Cbl} \rightleftarrows \mathrm{STZ} \cdot \mathrm{Cbl}$ was measured in the mixtures of the following composition: $\mathrm{H}_{2} \mathrm{O} \cdot \mathrm{Cbl}=33 \mu \mathrm{M}$, $\mathrm{STZ}=50 \mu \mathrm{M}$,

$$
\begin{aligned}
K_{\mathrm{d}} & =\frac{[\mathrm{Cbl}] \cdot[\mathrm{STZ}]}{[\mathrm{STZ} \cdot \mathrm{Cbl}]} ; \quad[\mathrm{STZ}] \\
& =[\mathrm{STZ}]_{0}-[\mathrm{STZ} \cdot \mathrm{Cbl}] ; \quad[\mathrm{STZ} \cdot \mathrm{Cbl}]=[\mathrm{Cbl}]_{0}-[\mathrm{Cbl}]
\end{aligned}
$$

$0.01 \mathrm{M} \mathrm{P}_{\mathrm{i}}$-buffer, pH $6.0(I \approx 0.01 \mathrm{M}), \mathrm{NaCl}=0.0-0.5 \mathrm{M}$, $22{ }^{\circ} \mathrm{C}$. Concentrations of free $\mathrm{H}_{2} \mathrm{O} \cdot \mathrm{Cbl}([\mathrm{Cbl}])$ were measured at time intervals in the supernatant using the absorbance coefficient $\varepsilon_{351}=25500 \mathrm{M}^{-1} \mathrm{~cm}^{-1}$. The value of $K_{\mathrm{d}}$ was calculated according to the above equation.

The dependences of $K_{\mathrm{d}}$ on time (Fig. 4b) and ionic strength (Fig. 4d) were plotted and analysed as explained in the main text.

The equilibrium dissociation constant was measured by incubation of $20 \mu \mathrm{M} \mathrm{H}_{2} \mathrm{O} \cdot \mathrm{Cbl}$ with different dilutions of STZ $(0-80 \mu \mathrm{M})$ for $24 \mathrm{~h}\left(22^{\circ} \mathrm{C}\right)$. The analysis of the binding curve $[\mathrm{STZ} \cdot \mathrm{Cbl}]$ vs. $[\mathrm{STZ}]_{\text {total }}$ was conducted using the square root equation [15].

\subsection{Purification of Cbl from cell extract}

Genetically improved cell line of Pseudomonas denitgrificans was used for production of cobalamin, see Ref. [19] as a review. Cell extract was prepared by a manufacturer of $\mathrm{B}_{12}$ by adding $\mathrm{H}_{2} \mathrm{SO}_{4}$ to the fermentation broth (final $\mathrm{pH}$ 3.7) and heating it for $15 \mathrm{~min}$ at $85^{\circ} \mathrm{C}$. No cyanide was present to avoid conversion of natural cobalamins to $\mathrm{CN} \cdot \mathrm{Cbl}$. Concentration of cobalamin in the extract $(320 \mu \mathrm{M})$ was measured spectroscopically after HPLC fractionation of a cyanide treated sample. The bulk of extract $(5 \mathrm{~L})$ was centrifuged and used for adsorption on the STZcolumn $(d=5 \mathrm{~cm}, h=12 \mathrm{~cm}, \approx 240 \mathrm{~mL})$. Adsorption on STZ was carried out in two cycles (20-24 h) with illumination of the extract at the entrance to the column. The illu- mination unit consisted of a $60 \mathrm{~W}$ lamp placed at the distance of $10 \mathrm{~cm}$ from a looped silicon tubing, $l=2 \mathrm{~m}$, $d=0.5 \mathrm{~cm}$, Buch and Holm (Denmark). Other lamps and tubings can be used as well. The column with adsorbed $\mathrm{Cbl}$ was sequentially washed with $\mathrm{H}_{2} \mathrm{O}(0.5 \mathrm{~L}), 0.5 \mathrm{M} \mathrm{NaCl}$ $(0.5 \mathrm{~L}), \mathrm{H}_{2} \mathrm{O}(1.5 \mathrm{~L})$, and equilibrated with approximately $200 \mathrm{~mL}$ of $20 \mathrm{mM} \mathrm{KCN}, 0.1 \mathrm{M} \mathrm{K}_{2} \mathrm{HPO}_{4} / \mathrm{K}_{3} \mathrm{PO}_{4}, \mathrm{pH} 12$, until a noticeable leakage of $\mathrm{Cbl}$ started. Elution was conducted in steps, where $100 \mathrm{~mL}$ fractions were eluted after $20 \mathrm{~h},+6 \mathrm{~h}$ and $+20 \mathrm{~h}$ of incubation $\left(22^{\circ} \mathrm{C}\right)$.

Desalting, removal of excessive cyanide and additional purification of the obtained sample was carried out in a $300 \mathrm{~mL}$ column packed with Amberlite XAD-2. The sample from STZ $(300 \mathrm{~mL},[\mathrm{Cbl}] \approx 5 \mathrm{mM})$ was loaded on XAD in three steps with $8-20 \mathrm{~h}$ incubation between each step. The column was washed with $3 \times 100 \mathrm{~mL}$ of $\mathrm{H}_{2} \mathrm{O}$ $(3 \times 30 \mathrm{~min})$ and $3 \times 100 \mathrm{~mL}$ of $5 \mathrm{mM}$ acetate $\mathrm{pH} 3.5$ $(3 \times 30 \mathrm{~min})$. Elution was conducted with $3 \times 100 \mathrm{~mL}$ of $20 \%$ 2-butanol $(3 \times 30 \mathrm{~min})$, whereupon $\mathrm{CN} \cdot \mathrm{Cbl}$ solution was lyophilized.

\section{Acknowledgement}

This work was supported by Lundbeck Foundation and Cobento A/S.

\section{References}

[1] J.M. Pratt, Inorganic Chemistry of Vitamin $\mathrm{B}_{12}$, Academic Press, London, New York, 1972.

[2] B. Kräutler, S. Ostermann, in: K.M. Kadish, K.M. Smith, R. Guilard (Eds.), The Porphyrin Handbook, vol. 11, Elsevier Science, USA, 2003, p. p. 229.

[3] E. Nexø, in: B. Kräutler, D. Arigoni, B.T. Goldding (Eds.), Vitamin $\mathrm{B}_{12}$ and $\mathrm{B}_{12}$-proteins, Wiley-VCH, Weineim, New York, 1998, p. 461.

[4] H.W. Baik, R.M. Russel, Annu. Rev. Nutr. 19 (1999) 357.

[5] R. Baanerjee, S.W. Ragsdale, Annu. Rev. Biochem. 72 (2003) 209.

[6] E. Nexø, H. Olesen, in: D. Dolphin (Ed.), B 12 , vol. 2, J. Wiley \& Sons Inc., New York, 1982, p. p. 57.

[7] S.N. Fedosov, L. Berglund, E. Nexø, T.E. Petersen, Patent WO 2006/ 024303, 2006.

[8] A.G. Cregan, N.E. Brasch, R. van Eldik, Inorg. Chem. 40 (2001) 1430

[9] S.N. Fedosov, L. Berglund, N.U. Fedosova, E. Nexø, T.E. Petersen, J. Biol. Chem. 277 (2002) 9989.

[10] G.I. Koldobskii, V.A. Ostrovskii, B.V. Gidaspov, Khim. Geterotsikl. Soedin. 6 (1975) 723.

[11] F. Himo, Z.P. Demko, L. Noodleman, K.B. Sharpless, J. Am. Chem. Soc. 124 (2002) 12210.

[12] F. Himo, Z.P. Demko, L. Noodleman, K.B. Sharpless, J. Am. Chem. Soc. 125 (2003) 9983.

[13] G.I. Koldobskii, V.A. Ostrovskii, Chem. Heterocycl. Compd. (USSR) 5 (1988) 469.

[14] W. Fieber, B. Hoffman, W. Schmidt, E. Stupperich, R. Konrat, B. Kräutler, Helv. Chim. Acta 85 (2002) 927.

[15] S.N. Fedosov, N.U. Fedosova, L. Berglund, S.K. Moestrup, E. Nexø, T.E. Petersen, Biochemistry 44 (2005) 3604.

[16] J. Wuerges, G. Garau, S. Geremia, S.N. Fedosov, T.E. Petersen, L. Randaccio, PNAS 103 (2006) 4386.

[17] P.L. Franke, W.L. Groeneveld, Transition Met. Chem. 6 (1981) 54.

[18] W.H. Pailes, H.P.C. Hogenkamp, Biochemistry 7 (1968) 4160.

[19] J.H. Martens, H. Barg, M.J. Warren, D. Jahn, Appl. Microbiol. Biotechnol. 58 (2002) 275. 